\title{
On Manzi: An Introduction
}

\author{
MATTHEW W. MOSCA \\ University of Washington \\ Volume 15, 2018
}

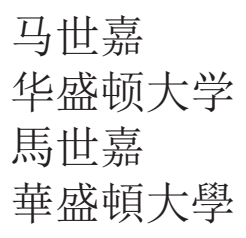

In the Dayi juemi lu 大義覺迷錄, the Yongzheng emperor claims that several terms used in early texts to refer to non-Chinese peoples were simply neutral descriptors of their geographic origins. Only in later centuries, in his view, were these terms misconstrued to have pejorative overtones. In the context of this discussion on the names applied to different peoples, the emperor made the following enigmatic assertion:

Moreover, Manchus would feel ashamed to be appended to the ranks of the Han Chinese. The Junghars call the Manchus manzi. All Manchus who hear this get furious and resent this. ${ }^{1}$

It is clear why a Manchu would be upset at being termed manzi, which can be translated as "[southern] savage." This reading, however, leaves several questions unanswered. First, if we interpret this term as "[southern] savage," it creates an apparent non sequitur: What does this Junghar term for the Manchus have to do with their shame at being described as Chinese? Second, since the Junghars did not speak or write Chinese, nor employ Chinese advisors, it is impossible that they could have used these specific offending characters to render the sound manzi. Third, if the Junghars described the Manchus as manzi, why was this not correctly interpreted simply as the Oirat word for "Manchu," but was rather imputed with a negative meaning? ${ }^{2}$

A partial solution to this riddle is found in a conversation recorded in the journal of Robert Hart. In 1865, the Manchu Grand Councilor and member of the Zongli Yamen

1. Dayi juemi lu (Taibei: Wenhai chubanshe, 1966): 85 (j. 1.43a).

況滿洲人皆恥附於漢人之列, 準噶爾呼滿洲為蠻子, 滿洲聞之, 莫不忿恨之

2. G. J. Ramstedt gives the reading mandž! (eastern Oirat reading mandžn). Kalmückisches Wörterbuch (Helsinki: SuomalaisUgrilainen Seura, 1935), 255. 
Bao-yun 寶鋆 told him, "Every one must submit to being nick-named: the Chinese call us 'Saou ta tsze' [臊鞋子] (stinking Tartars), we call them 'Han Man tsze' [漢蠻子] ...." Under these circumstances, Hart was told, Westerners should not take umbrage when they in their turn were described as "foreign devils" (洋鬼子). ${ }^{3}$ Interestingly, this usage is corroborated by the Qianlong emperor. Famously sensitive to slights against the Manchus, he took a surprisingly relaxed attitude toward this verbal practice:

Manchus informally term Han people "Manzi," and the Han also informally call Manchus "Dazi." This is only a reference to their home regions. ${ }^{4}$

In other words, on the streets of Beijing a Manchu might be a "Tartar" or even a "stinking Tartar," but he could retort that his Han Chinese interlocutor was a manzi or "southern savage." What seems to have enraged Yongzheng, and the reading that makes the most sense in this context, is the belief that the Junghars were not simply calling the Manchus "[southern] savages," but that by implication this meant "Chinese."

This leaves open three intriguing possibilities. One is that Yongzheng had genuinely misinterpreted the Junghar name for the Manchus, not realizing that manzi simply meant "Manchu." Another is that Yongzheng was deliberately fabricating grounds to level a charge against the hated Junghars for political reasons. A third possibility is that the Junghars did in fact refer to the Manchus as "Chinese," and Yongzheng chose to translate Oirat term they had used into Chinese as manzi because he felt it had insulting overtones. To shed more light on this question, Dr. Hosung Shim has kindly agreed to write the following authoritative and fascinating study of Oirat terms for the Manchus.

\section{Bibliography}

Dayi juemi lu 大義覺迷錄. Taibei: Wenhai chubanshe, 1966.

Hart, Robert. Robert Hart and China's Early Modernization: His Journals, 1863-1866. Cambridge, Mass.: Council on East Asian Studies, Harvard University, 1991.

Qing shilu 清實錄. Beijing: Zhonghua shuju, 1985-1987.

Ramstedt, G. J. Kalmückisches Wörterbuch. Helsinki: Suomalais-Ugrilainen Seura, 1935.

3. Robert Hart, Robert Hart and China's Early Modernization: His Journals, 1863-1866 (Cambridge, Mass.: Council on East Asian Studies, Harvard University, 1991), 327.

4. Qing shilu 清實錄 (Beijing: Zhonghua shuju, 1985-1987), j. 484, Qianlong 20/3/13.

滿洲俗稱漢人曰蠻子, 漢人亦俗稱滿洲曰達子, 此不過如鄉籍而言 